\title{
Pengembangan Desa Wisata Edukasi Berbasis Implementasi Kompos Buatan di Desa Puyung, Jonggat, Lombok Tengah
}

\author{
Development of Educational Tourism Village Based on Hush Ash Compost \\ Implementation in Puyung Village, Jonggat, Central Lombok
}

\author{
Sri Puji Astuti, Rina Kurnianingsih, Siti Rosidah, Eka Sunarwidhi Prasedya, \\ Candra Dwipayana Hamdin, Mursal Ghazali, Sunarpi
}

\author{
Program Studi Biologi, FMIPA Universitas Mataram,e-mail: spastuti@unram.ac.id
}

\begin{abstract}
Abstrak
Kegiatan PPM Universitas Mataram dengan sasaran siswa-siswi sekolah di pondok pesantren yayasan GMC, petani dan buruh tani, pengrajin tahu dan tempe, pemuda-pemudi di lingkungan Desa Puyung telah selesai dilaksanakan. Kegiatan ini bertujuan untuk mendorong siswa dan masyarakat untuk terus memproduksi kompos berbahan dasar abu sekam dan terus memanfaatkannya dalam bidang pertanian, membantu masyarakat setempat dalam mengembangkan Desa Puyung sebagai kawasan wisata edukasi, dengan beberapa centra obyek edukasi diantaranya: obyek pembuatan tahu dan tempe yang memanfaatkan ampas gabah sebagai bahan bakar, obyek pengolahan sampah abu sekam hasil pembakaran ampas gabah dibuat warga menjadi kompos buatan, obyek lahan percobaan sekolah dan lahan pertanian sebagai tempat aplikasi kompos buatan. Metode yang digunakan adalah pendekatan sosialisasi, pelatihan, pendampingan dan pengembangan yang melibatkan siswa dan masyarakat Desa Puyung dengan menerapkan Applied Group Discuss (AGD) berdasarkan potensi pengembangannya obyek wisata edukasi. Kegiatan dilanjutkan dengan praktik teknis tour guide di lokasi lahan percobaan sekolah. Dilakukan evalusi dengan metode observasi dan tanya jawab terhadap ketercapaian kegiatan tersebut. Kesimpulan dari evaluasi kegiatan ini, lebih dari $85 \%$ peserta memahami materi yang disampaikan, sebanyak $65 \%$ peserta mampu mempraktikan kembali simulasi dan demonstrasi yang diberikan, sebanyak $90 \%$ peserta termotivasi untuk mewujudkan desa wisata edukasi di Desa Puyung.
\end{abstract}

Kata kunci: wisata edukasi, implementasi kompos buatan, Desa Puyung

\begin{abstract}
The community service activities from Mataram University have been done, the target audiences were students at the GMC boarding school, farmers, tofu and tempe craftsmen, young people in the Puyung Village. The aims of the activity were to encourage students and the community to continue to produce compost made from husk ash and continue to use it in agriculture, to helping local communities to developing Puyung Village as an educational tourism area, with several educational objects including: tofu and tempe processing using rice grain as fuel, the tourism object of the processing compost using husk ash waste made by local communities, the tourism object of school experimental land and agricultural land as an application for compost. The methods were used socialization, training, mentoring and development involving students and the community of Puyung Village by applying the Applied Group Discuss (AGD) based on the potential for developing educational tourism objects. The activity continued with the technical practice of tour guides at the school experimental land. Evaluation was carried out with observation, question and answer methods for the achievement of these activities. The conclusions of the evaluation activity, were obtained more than $85 \%$ of participants understood the material presented, $65 \%$ of participants were able to repractice the simulation and demonstration provided, $90 \%$ of participants were motivated to realize educational tourism villages in Puyung Village.
\end{abstract}

Key words: educational tourism, implementations of compost, Puyung village 


\section{PENDAHULUAN}

Pengembangan wisata di propinsi Nusa Tenggara Barat khususnya di Pulau Lombok dan Pulau Sumbawa terus digaungkan, baik oleh pemerintah daerah maupun masyarakat setempat. Pemerintah daerah sangat menekankan pembentukan dan pengembangannya berbasis pada aspekaspek sumber daya alam desa dan sumber daya manusia, untuk lebih memperkenalkan desa dengan ciri khasnya masing-masing (Subarkah, 2017), sehingga menjadi icon tersendiri. Dukungan diberikan dengan melibatkan pihak-pihak akademisi dalam menggali dan mengkaji potensi-potensi desa, memberikan pelatihan dan pendampingan serta membantu dalam pemasaran dan sosialisasinya, baik dalam tingkat lokal, nasional maupun internasional. Beberapa kerjasama dengan pihak swasta dijalin demi perluasan jaringan distribusi produk maupun jasa yang dihasilkan oleh masing-masing desa potensi.

Desa Puyung merupakan salah satu desa yang berada di kecamatan Jonggat kabupaten Lombok Tengah, letaknya sangat strategis, berada di dekat jantung kota Praya, menjadikan akses desa ini sangat dekat menuju Bandara Internasional Lombok dengan jarak sekitar 15 menit. Selain itu, akses desa ini dekat dengan pantai Kuta sebagai Kawasan Ekonomi Khusus, berjarak sekitar 45 menit (Khalik, 2014). Posisinya yang strategis menjadikan Desa Puyung sebagai posisi emas kawasan tujuan wisata.

Sekitar 65\% masyarakat Desa Puyung bermata pencaharian sebagai pengrajin tahu dan tempe, $35 \%$ sisanya sebagai petani, buruh tani dan lain-lain. Pengrajin tahu dan tempe, keseharian operasional produksinya memanfaatkan ampas gabah padi sebagai bahan bakarnya, yang nantinya akan menghasilkan abu sekam. Abu sekam hasil pembakaran telah dimanfaatkan sebagai bahan baku pembuatan pupuk kompos (Astuti dan Kurnianingsih, 2019). Penggunaan kompos berbahan baku abu sekam ini sudah meluas, baik oleh warga yang tinggal di desa maupun disekitar Desa Puyung, pemanfaatannya pun beranekaragam, baik digunakan sendiri sebagai pupuk di lahan pertanian maupun dikomersilkan.

Kompos buatan dari abu sekam dapat dijadikan sebagai produk icon Desa Puyung, mengingat bahan baku abu sekam hasil pembakaran dapat dengan mudah diperoleh di desa itu. Selain itu, Desa Puyung juga sebagai zona sekolah, terbukti banyak ditemukannya sekolah negeri maupun swasta yang berbasis pondok pesantren atau kawasan pendidikan yang syarat akan suasana religius. Disamping itu, posisi emas Desa Puyung sebagai wilayah strategis yang dekat dengan kawasan wisata ekonomi khusus menjadikannya sebagai desa yang memiliki potensi besar untuk dikembangkan menjadi wisata edukasi berbasis ekologi.

Diharapkan dengan adanya sosialisasi mengenai wisata edukasi berbasis implementasi kompos buatan di yayasan pondok pesantren Generasi Muslim Cendekia (GMC) Desa Puyung yang melibatkan siswa dan masyarakat, dapat memaksimalkan pemanfatan pupuk kompos buatan di lahan percobaan siswa dan lahan pertanian, memperkaya pengetahuan dan bekal keterampilan siswa dan masyarakat sebagai pemandu/ tour guide wisata edukasi ekologi sehingga mereka dapat mengedukasi pengunjung dan masyarakat mengenai cara pembuatan kompos berbahan dasar abu sekam, manfaat aplikasi kompos pada lahan pertanian. Selain itu, rangkaian hasil kegiatan ini dapat menjadi pionir wisata edukasi di Kabupaten Lombok Tengah dan menginisiasi pengembangan wisata edukasi di wilayah lain.

\section{SOLUSI/TEKNOLOGI}

Pelatihan pengembangan desa wisata edukasi berbasis implementasi kompos buatan dilakukan dengan pendekatan sosialisasi, pelatihan, pendampingan dan pengembangan yang melibatkan siswa dan masyarakat Desa Puyung; mendorong siswa 
dan masyarakat untuk terus memproduksi kompos berbahan dasar abu sekam dan terus memanfaatkannya dalam bidang pertanian, sehingga akan nampak keunggulan dari pupuk buatan tersebut; tujuan berikutnya membantu masyarakat setempat dalam mengembangkan Desa Puyung sebagai kawasan wisata edukasi, dengan beberapa centra obyek edukasi diantaranya: pembuatan tahu dan tempe yang memanfaatkan ampas gabah sebagai bahan bakar, sampah abu sekam hasil pembakaran ampas gabah dibuat warga menjadi kompos buatan, aplikasi kompos buatan di lahan percobaan sekolah dan lahan pertanian.

Kegiatan Pengabdian Pada Masyarakat (PPM) melibatkan anggota tim berpengalaman dibidang kompos, ekologi, fisiologi tumbuhan dan edukasi dengan latar belakang keilmuan yang relevan dengan kebutuhan audiens. Dukungan terhadap kegiatan ini juga diberikan oleh Kepala Desa Puyung, Kepala Dusun Lingkung Daye beserta jajarannya, terbukti dengan diberikanya kesempatan kepada seluruh masyarakat di Desa Puyung untuk berperan aktif mengikuti kegiatan ini dari awal sampai akhir acara. Pembinaan dan pendampingan terus dilakukan oleh tim PPM Universitas Mataram (Unram) berdasarkan kelompok-kelompok pengembangan jenis wisata edukasi yang di inginkan.

Manfaat yang dapat dirasakan oleh peserta dengan diselenggarakannya kegiatan ini adalah bertambahnya pengetahuan masyarakat Desa Puyung dan siswa-siswa di pondok pesantren GMC mengenai gambaran konsep/ model desa wisata dan manfaatnya bagi masyarakat sekitar; memperoleh gambaran adanya alternatif lain tempat pemasaran dan pemanfaatan kompos buatan yang diproduksi warga; transfer ilmu kepada para siswa-siswi GMC, mengenai mekanisme fisiologi tumbuhan dan fungsi ekologis dengan memanfaatkan kompos buatan dalam mensuplai dan memperkaya unsur hara tanah; peranan fungsi dan manfaat menggunakan kompos buatan di bidang pertanian; masyarakat Desa Puyung dapat memanfaatkan peluang pelatihan dan pendampingan ini untuk meningkatkan keterampilan dan menambah sumber penghasilan baru.

Awal kegiatan, seluruh peserta dikumpulkan untuk mendapatkan materi mengenai alternatif lain pemasaran dan pemanfaatan kompos buatan warga, mengaplikasikan kompos buatan di lahan percobaan sekolah-sekolah, memberi gambaran konsep/ model desa wisata edukasi yang mungkin untuk dikembangkan di Desa Puyung. Kegiatan dilanjutkan dengan mengelompokkan peserta berdasarkan potensi dan kebutuhan pendampingannya, kegiatan ini menggunakan pendekatan teknik diskusi Applied Group Discuss (AGD). Berdasarkan potensi dan kebutuhannya dibentuk kelompok-kelompok yang terdiri dari petani dan buruh tani, pengrajin tahu tempe, pemuda desa dan pelajar sekolah.

Masing-masing anggota tim PPM memberikan pendampingan kepada setiap kelompok diskusi. Materi pada kelompok pengrajin tahu tempe menekankan pada wisata edukasi cara pembuatan tahu tempe menggunakan bahan bakar yang ramah lingkungan yakni dari gabah padi, kemudian abu sekam sisa pembakaran agar tidak dibuang tetapi ditampung untuk dimanfaatkan dalam pembuatan kompos.

Materi pada kelompok petani dan buruh tani menekankan pada wisata edukasi cara menanam padi organik menggunakan media tanah yang telah di campur dengan kompos buatan warga, dan wisata edukasi memanen padi, dimana sisa gabah hasil penggilingan padi tidak dibuang tapi dapat dimanfaatkan sebagai bahan bakar alami pembuatan tahu dan tempe.

Materi pada kelompok pemuda desa dan pelajar sekolah menekankan pada teknik pembuatan kompos menggunakan bahan baku abu sekam; teknik aplikasi kompos buatan di lahan pertanian, lahan percobaan sekolah, dan di pekarangan apotik hidup milik warga. Selain itu, diberikan materi mengenai alasan dan manfaat menggunakan kompos buatan sehingga adanya transfer 
ilmu bidang ekologi, perkembangan dan fisologi tumbuhan kepada siswa-siswi GMC. Materi tidak sebatas keilmuan di bidang biologi saja, namun diberikan juga bekal materi dan teknik menjadi seorang tour guide yang nantinya akan memberikan informasi kepada para pengunjung terkait dengan obyek desa wisata Puyung.

Langkah-langkah yang dilaksanakan pada kegiatan PPM meliputi:

1. Tim PPM Unram melakukan koordinasi dengan Kepala Desa Puyung dan Pimpinan Pondok Pesantren GMC dan jajarannya, terkait perijinan dan model kegiatan.

2. Tim PPM Unram berkoordinasi dengan Kepala Desa Puyung, Pimpinan Pondok Pesantren GMC, dan mahasiswa terkait undangan, teknis kegiatan dan pembagian kelompok diskusi berdasarkan materi dan pendampingan.

3. Persiapan alat dan bahan kegiatan.

4. Tim PPM unram dan mahasiswa berkoordinasi melakukan perbandingan dan pengamatan terhadap hasil panen yang menggunakan pupuk kompos buatan warga dengan yang tidak menggunakan pupuk kompos buatan. Dilakukan di lahan percobaan milik pondok pesantren yayasan GMC.

5. Menjelaskan materi mengenai alternatif lain pemasaran dan pemanfaatan kompos buatan warga,

6. Memberi gambaran konsep/ model desa wisata edukasi yang mungkin untuk dikembangkan di Desa Puyung.

7. Menjelaskan materi wisata edukasi cara pembuatan tahu tempe menggunakan bahan bakar yang ramah lingkungan yakni dari gabah padi, kemudian abu sekam sisa pembakaran tidak dibuang tetapi ditampung untuk dimanfaatkan sebagai bahan baku pembuatan kompos, materi diberikan kepada kelompok pengrajin tahu dan tempe.

8. Menjelaskan materi wisata edukasi cara menanam padi organik menggunakan media tanah yang telah di campur dengan kompos buatan warga, dan wisata edukasi memanen padi, dimana sisa gabah hasil penggilingan padi tidak dibuang tapi dapat dimanfaatkan sebagai bahan bakar alami pada proses pembuatan tahu dan tempe, materi diberikan kepada kelompok petani dan buruh tani.

9. Menjelaskan materi aplikasi pupuk kompos buatan menggunakan bahan baku abu sekam; teknik aplikasi kompos buatan di lahan pertanian, lahan percobaan sekolah, dan di pekarangan apotik hidup milik warga. Selain itu, diberikan materi mengenai alasan dan manfaat menggunakan kompos buatan dalam kacamata keilmuan bidang ekologi, perkembangan dan fisologi tumbuhan kepada siswa-siswi GMC.

10. Menjelaskan materi dan teknik menjadi seorang tour guide yang baik kepada kelompok pemuda desa, pelajar sekolah dan masyarakat, yang nantinya akan memberikan informasi kepada para pengunjung terkait dengan obyek desa wisata Puyung.

11. Mendemonstrasikan teknik menjadi tour guide desa wisata edukasi sambil mengunjungi lahan percobaan tanaman cabe dan tomat sebagai wujud aplikasi penggunaan pupuk kompos buatan.

12. Mensimulasi peserta melalui pertanyaan dan diskusi.

13. Melakukan evaluasi kegiatan dengan metode observasi.

\section{HASIL DAN DISKUSI}

Kegiatan PPM dihadiri oleh siswasiswi dan para guru di pondok pesantren yayasan GMC; petani dan buruh tani; pengrajin tahu dan tempe; pemuda dan masyarakat Desa Puyung. Materi disampaikan dalam bentuk ceramah, demostrasi, tanya jawab, praktik dilahan percobaan sekolah. Kegiatan ini semakin menarik perhatian peserta, selain penyampaian menggunakan metode AGD, pengelompokkan peserta dilakukan berdasarkan muatan materi dan 
pendampingannya, Gambar 1 dan Gambar 2.

Kegiatan ini memperoleh respon yang positif dari peserta, mereka sangat antusias mengikuti kegiatan dari awal hingga akhir, setiap kelompok aktif bertanya dan merespon setiap pertanyaan yang diberikan. Beberapa hambatan ditemui oleh tim PPM, diantaranya paradigma yang berkembang di masyarakat dan peserta mengenai wisata adalah segala sesuatu yang dapat dijual dan bernilai seni; penikmat wisata adalah orang asing yang berasal dari luar negeri; minimnya pengetahuan masyarakat mengenai wisata edukasi, model dan contoh-contoh penerapannya; hal-hal unik tidak dapat dijadikan sebagai icon wisata; wisata tidak dapat melibatkan satu desa atau sekolah, cukup unit terkecilnya saja; dan seorang tour guide tidak perlu menguasai semua materi, cukup dapat berbahasa inggris saja.

Masyarakat sudah memproduksi sendiri pupuk kompos dari abu sekam, beberapa petani menerapkannya di lahan pertanian, pupuk kompos buatan ini juga sudah di aplikasikan ke lahan percobaan sekolah. Pengamatan di lahan percobaan sekolah terhadap tanaman yang diberi kompos buatan dengan yang tidak. Masyarakat dapat menjual pupuk kompos buatan di toko-toko tanaman dan lahan percobaan sekolah.

Kelompok pengrajin tahu dan tempe dapat menjadikan aktivitas pembuatan tahu dan tempe sebagai salah satu tujuan wisata edukasi bagi anak-anak sekolah dan para wisatawan. Pada kelompok petani dan buruh tani dapat menjadikan aktivitas mereka disawah sebagai salah satu tujuan wisata edukasi bagi para wisatawan. Pada kelompok pemuda dan pelajar, siswa-siswi dapat menjadi tour guide cilik bagi wisatawan yang berkunjung ke lokasi Desa wisata Puyung maupun ke lahan percobaan sekolah, mereka dapat menjelaskan proses perkembangan dan fisiologi tumbuhan secara biologis, sehingga mampu megedukasi para wisatawan. Kepada masyarakat dan pejabat desa diberikan gambaran dan model desa wisata dan kemungkinan pengembangan obyek-obyek wisata edukasi di setiap potensi desanya.

Kegiatan PPM ini dilanjutkan dengan kunjungan ke lahan percobaan sekolah GMC, disela-sela itu sekaligus didemostrasikan proses penjelasan mengenai pertumbuhan tanaman menggunakan pupuk buatan (Gambar 3).

Secara garis besar, kegiatan PPM ini telah menambah wawasan peserta terhadap model desa wisata yang mungkin dikembangkan di Desa Puyung, kegiatan bertani, bercocok tanam dan mebuat tahu tempe tidak hanya sekedar rutinitas yang dikerjakan setiap hari tetapi juga dapat dijadikan sebagai sarana wisata edukasi yang menjadi ciri khas/ icon wisata di Desa Puyung yang dapat dinikmati dan dilakukan oleh semua kalangan pengunjung. Peserta dan warga setempat mengharapkan adanya pendampingan terus menerus dari tim PPM unram selama pembentukan dan evaluasi wisata edukasi Desa Puyung. Selain itu, tim PPM diharapkan dapat memberikan ide-ide kreatif dalam mendorong masyarakat untuk menciptakan obyek-obyek wisata edukasi lain yang mungkin dibentuk di Desa Puyung berdasarkan sumberdaya yang mereka miliki. Dengan demikian, efek jangka panjang dari pengelolaannya mampu menambah penghasilan warga dan meningkatkan kesejahteraan dan taraf hidup masyarakan di Desa Puyung dan masyarakat sekitarnya.

Tercapainya manfaat dari kegiatan ini adalah dengan pertanyaan yang diajukan oleh peserta dan kesan-kesan yang disampaikan oleh para peserta selama kegiatan berlangsung. Hasil evaluasi kegiatan ini menunjukkan bahwa lebih dari $85 \%$ peserta memahami materi yang disampaikan, sebanyak $65 \%$ peserta mampu mempraktikan kembali simulasi dan demonstrasi yang diberikan, sebanyak $90 \%$ peserta termotivasi untuk mewujudkan desa wisata edukasi di Desa Puyung. 


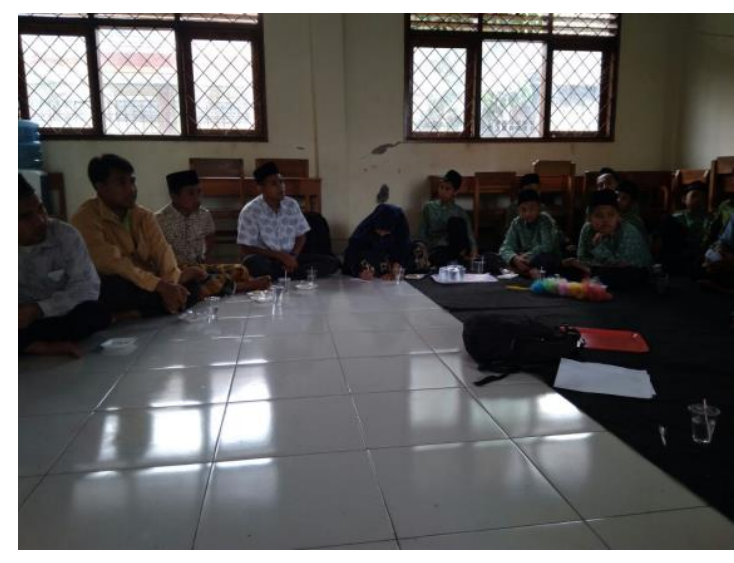

Gambar 1. Applied Group Discuss pada kelompok siswa dan pemuda desa

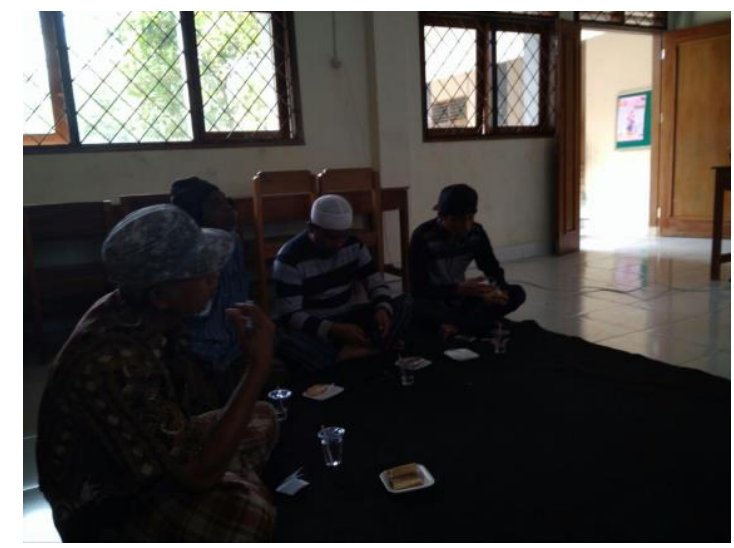

Gambar 2. Applied Group Discuss pada kelompok pengrajin tahu tempe dan petani

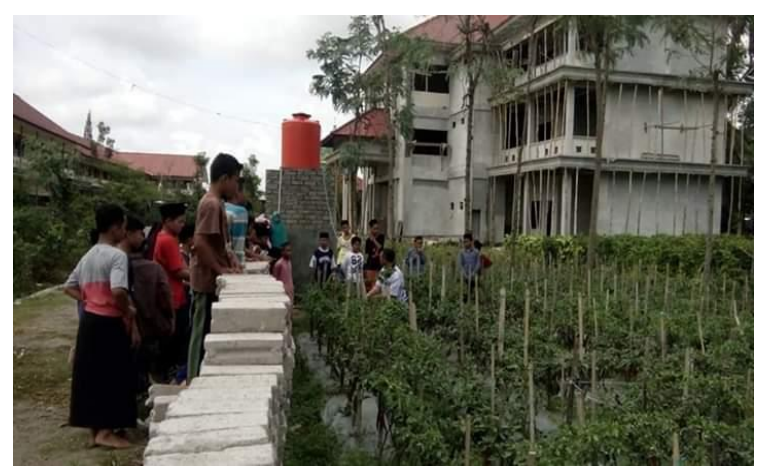

Gambar 3. Demostrasi dan praktik tour guide kepada pemuda dan siswa sekolah di lahan percobaan sekolah GMC

\section{KESIMPULAN}

Kesimpulan dari kegiatan PPM ini adalah, peserta memperoleh gambaran model desa wisata edukasi, materi-materi yang diberikan sangat menarik menambah pengetahuan peserta terhadap teknik dan unit-unit rutinitas yang dapat dijadikan sebagai obyek wisata, teknik menyampaikan dan demonstrasi yang dilakukan oleh tim PPM dalam kelompok-kelompok diskusi sangat memudahkan peserta dalam melihat potensi ekonomi yang mungkin untuk diperdalam dan dikembangkan. Selain itu, materi-materi perkembangan dan fisiologi tumbuhan serta ekologi mampu menambah pengetahuan mereka dalam bidang biologi.

\section{UCAPAN TERIMA KASIH}

Lembaga Penelitian dan Pengabdian Masyarakat Universitas Mataram, Kepala Dusun Lingkung Daye, Kepala Desa Puyung Kecamatan Jonggat Kab. Lombok Tengah, Ketua Pondok Pesantren Yayasan GMC Desa Puyung beserta seluruh staf guru, siswa-siswi pondok pesantren Yayasan GMC, Ketua kelompok pengrajin tahu tempe Dusun Lingkung Daye, petani dan buruh tani di Desa Puyung, pemudapemudi dan seluruh warga masyarakat Dusun Lingkung Daye Desa Puyung, mahasiswa KKN Unram dan semua pihak yang telah ikut berpartisipasi dan mensukseskan kegiatan PPM Unram.

\section{PUSTAKA}

Astuti, SP. Faturrahman. Gunawan, ER. Novida, S. 2015. Aplikasi Teknik Mikrobial Dalam Pembuatan Kompos Menggunakan Limbah Padat Organik Jerami Padi Dengan Stimulator Limbah Leri. Jurnal Abdi Insani Unram. 2 (2). 8-13.

Astuti, SP. dan Kurnianingsih, R. 2019. Pembuatan Kompos Padat Dari Limbah Abu Sekam yang Ramah Lingkungan di Desa Puyung. Jurnal Pengabdian Masyarakat MIPA dan Pendidikan MIPA UNY. 5 (1). 27-33.

Khalik W. 2014. Kajian Keamanan dan Kenyamanan Wisatawan di Kawasan Pariwisata Kuta Lombok. Jurnal 
Master pariwisata Universitas Udayana. 1 (1). 23-42.

Subarkah, AR. 2017. Strategi City Branding Nusa Tenggara Barat
Menjadikan Lombok sebagai Destinasi Pariwisata Halal. Jurnal Political Science. UMM. 